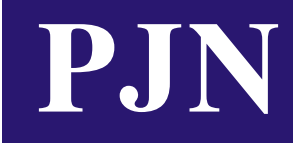

ISSN 1680-5194

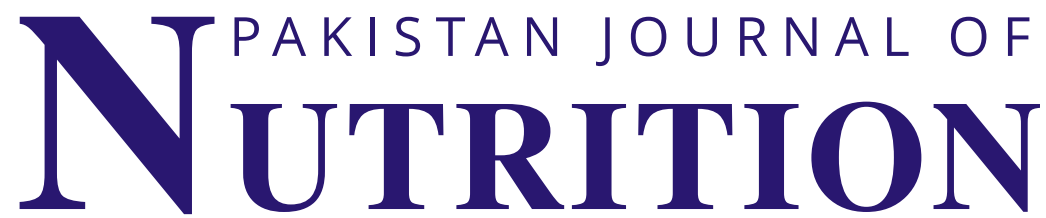

ANSI迫e佔

308 Lasani Town, Sargodha Road, Faisalabad - Pakistan Mob: +92 3003008585 , Fax: +92 418815544

E-mail: editorpjn@gmail.com 


\title{
A Simple Nutrition Screening Tool for Detecting Stunting of Pre-Schoolers: Development and Validity Assessment
}

\author{
${ }^{1}$ Haripin Togap Sinaga, ${ }^{2}$ Alfridsyah, ${ }^{1}$ Berlin Sitanggang and ${ }^{2}$ Abdul Hadi \\ ${ }^{1} J u r u s a n$ Gizi, Politeknik Kesehatan Medan, Indonesia \\ Jurusan Gizi, Politeknik Kesehatan Aceh, Indonesia
}

\section{Abstract}

Background and Objective: Routine height measurement for school children has been conducted for 110 years. However, the validity of height measurement tools are questionable and have resulted in varying practices and data of stunting prevalence. This study aimed to assess the sensitivity of the wall growth chart for use as a nutrition screening tool in kindergarten schools. Materials and Methods: This study was a cross-sectional study. A total sample of 180 pre-schoolers were involved and recruited from eight kindergarten schools in Deli Serdang district. Each child was measured using a wall growth chart and the gold standard. A validity test was conducted to determine six validity indices; sensitivity, specificity, positive predictive value, negative predictive value, false negative and true positive. Results: The height measurements from the wall growth chart and the gold standard were quite similar. The validity indices showed that the wall growth chart had strong sensitivity and specificity, at 91.0 and $92.0 \%$, respectively. The prevalence of stunting detected by both tools ( 21.7 vs $19.4 \%$ ) was not significantly different ( $<<0.00)$. Conclusion: Wall growth charts demonstrate high validity and reliability for use as a nutrition screening tool. In future use, this tool has an ability of at least $81.5 \%$ to correctly detect stunted and normal children. The use of this tool may assist the Indonesia Education Act to conduct growth monitoring and properly prevent stunting in school children.

Key words: Nutrition screening tool, validity, sensitivity, specificity, stunting

Received: December 13, $2017 \quad$ Accepted: February 28, $2018 \quad$ Published: April 15, 2018

Citation: Haripin Togap Sinaga, Alfridsyah, Berlin Sitanggang and Abdul Hadi, 2018. A simple nutrition screening tool for detecting stunting of pre-schoolers: Development and validity assessment. Pak. J. Nutr., 17: 236-241.

Corresponding Author: Haripin Togap Sinaga, Jurusan Gizi, Politeknik Kesehatan Medan, Indonesia

Copyright: @ 2018 Haripin Togap Sinaga etal. This is an open access article distributed under the terms of the creative commons attribution License, which permits unrestricted use, distribution and reproduction in any medium, provided the original author and source are credited.

Competing Interest: The authors have declared that no competing interest exists.

Data Availability: All relevant data are within the paper and its supporting information files. 


\section{INTRODUCTION}

Historically, routine height measurement for school children began 110 years ago, when the Education Act of 1907 introduced periodic child nutritional inspection in schools to address the concern of poor nutrition' ${ }^{1}$. Several countries have conducted a single height measurement around the age of 5 years since $1988^{2-5}$, while Indonesia has conducted routine height measurements at primary school entry since 1987. The target was to find the prevalence of stunted children at approximately 6-7 years old 6 .

The current move towards school health care in Indonesia indicates a need for an effective and simple nutrition screening tool that can be used by all levels, particularly at school health facilities.

Currently, the most commonly used height measurement tools are microtoises, wooden rulers and tapes. Each type of height-screening tool has resulted in variable practices and data of stunting across regions ${ }^{7,8}$. The validity of these tools are questionable because the accuracy and experience of a given measures are not considered. The criterion-related validity of a screening tool is determined by evaluating sensitivity, specificity and positive predictive value. Sensitivity is defined as the tool's ability to correctly identify the individuals at nutritional risk and specificity is the tool's ability to correctly identify the individuals not at nutritional risk'

Therefore, the sensitivity and specificity of the screening tools should be carefully considered. According to Habicht ${ }^{10}$, in order to obtain high coverage and cost efficiency in community nutrition intervention, a screening tool should have high sensitivity and a high positive predictive value (both $>80.0 \%$ ).

Various nutrition screening tools have been developed but most have focused on hospital patients ${ }^{11-14}$. However, simple nutrition screening tools for height measurement of healthy children are very limited.

An anthropometric growth chart to be used as a screening tool for children aged 6-12 years old. However, it has low sensitivity (66.0\%) and low positive predictive value ${ }^{15}$. In this study, the wall growth chart was developed to measure the heights of pre-school aged 4-5 years old. It is expected to be a simple and effective tool for height measurement in kindergarten schools. In Indonesia, the number of kindergarten schools has increased significantly in the last 5 years. In 2014, there were 75,000 kindergarten schools with five million pupils aged 3-6years old. Considering that growth monitoring is a compulsory programme at kindergarten schools ${ }^{16}$, a simple and valid screening tool is highly expected. This study aimed to determine the sensitivity and specificity of the wall growth chart.

\section{MATERIALS AND METHODS}

Location of study: This study was a cross-sectional validation study involving 180 pre-school children aged 4-5 years old who were recruited from eight kindergarten schools. The schools were located in peri-urban areas of Deli Serdang District in North Sumatera Province. Deli Serdang is one of the largest areas among 33 districts in North Sumatera Province, with a total population of 2,029,380 ${ }^{17}$.

Eight kindergarten schools were selected according to the following criterias: The ratio of teachers to students was 1-10, the learning room was permanent, a school health programme was in place and a complete school administration was in place. The study was conducted during May-September, 2017.

Sample calculation: The sample size was calculated using the following formula ${ }^{15}$ :

$$
\mathrm{n}=\frac{\mathrm{Z}_{1-\alpha / 2}{ }^{2} \times \mathrm{P} \times(1-\mathrm{P})}{\mathrm{d}^{2}}
$$

where, $\mathrm{p}$ was assumed to have an expected sensitivity of $85 \%$ and $d=$ Standard error $6 \%$ :

$$
\mathrm{n}=\frac{1.64^{2} \times 0.85 \times(1-0.85)}{0.06^{2}}
$$

$\mathrm{n}=16$, then $\mathrm{n}^{\prime}$ was calculated by the formula $\mathrm{n}^{\prime}=\frac{\mathrm{n}}{\mathrm{P}_{1}}$, where $\mathrm{P} 1$ was the prevalence of stunting, which was $37.2 \%$ :

$$
\mathrm{n}^{\prime}=\frac{61}{0.3720}
$$

$\mathrm{n}^{\prime}=164$. About $10 \%$ was added for drop-out possibility, yielding a total sample size of 180 subjects. Flow chart of study is shown in Fig. 1.

Developing wall growth chart: The idea of creating a wall growth chart emerged when reseachers found a variation in practices of height measurement and varying data of stunting prevalence across districts in North Sumatera Province. The wall growth chart is a modified chart based on anthropometric reference data on height-for-age compiled 


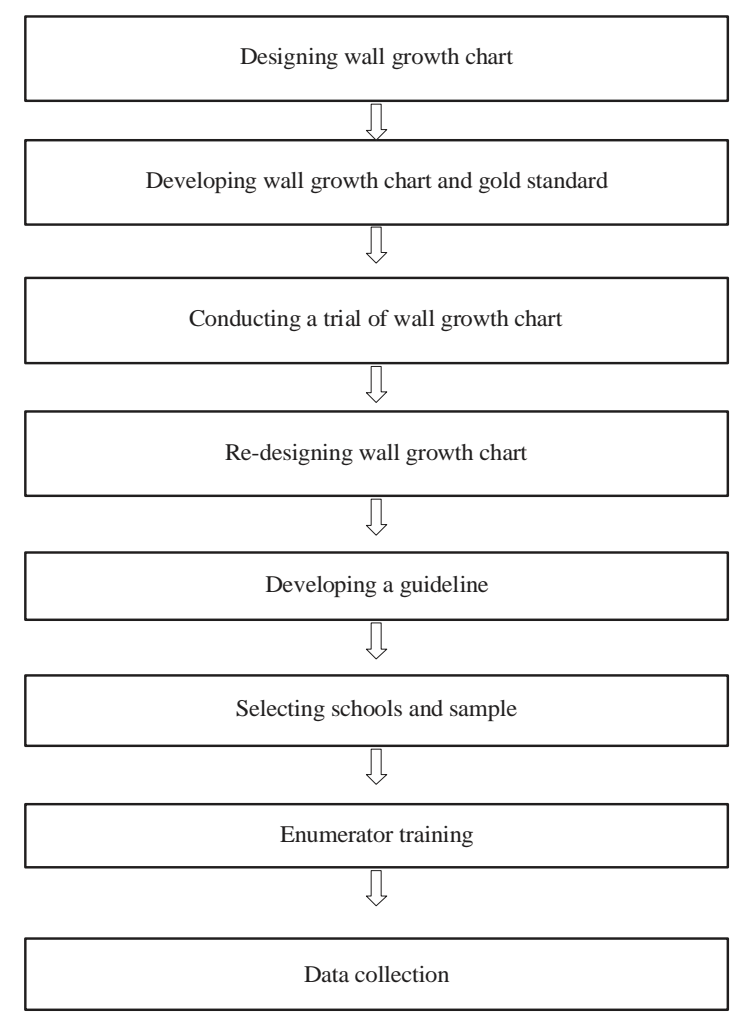

Fig. 1: Flow chart of study

by WHO-2005 18,19 . It is made from a thick plastic material with the size $150 \times 200 \mathrm{~cm}$. The horizontal lines show the height $(0-130 \mathrm{~cm})$ and 13 vertical lines show the child's age in months (48-60 months).

The range between the horizontal lines is $0.5 \mathrm{~cm}$ and the accuracy of the wall growth chart is $5.0 \mathrm{~mm}$, i.e., $91.5,92.0$ and $92.5 \mathrm{~cm}$, while the gold standard as $1.0 \mathrm{~mm}$.

There are four different colours on the growth chart; red, yellow, light green and dark green. These different colours present the height status. If the top of the child's head lies on the red tape, then the child is severely stunted in growth. In addition, the yellow tape means stunting, the light green tape means normal and the dark green tape means the child is tall.

Gold standard measurement: The gold standard measurement was made from a wooden board with a size of $200 \times 35 \mathrm{~cm}$. Two metal tapes were attached on the left and right side, with a microtoise in between. The accuracy of gold standard is $0.1 \mathrm{~cm}$. i.e., $91.1,91.2$ or $91.3 \mathrm{~cm}$.

Enumerator training: Ten enumerators were recruited from an academy of nutrition students. They were trained for 2 days to understand how to use the wall growth

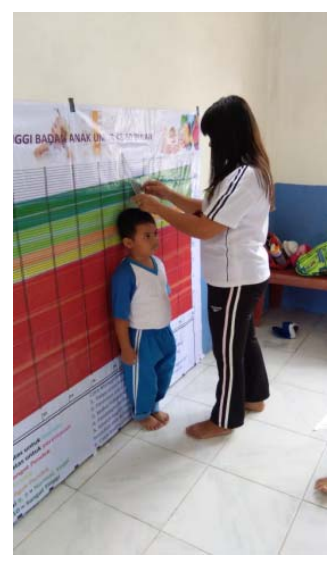

Fig. 2: Individual measurement

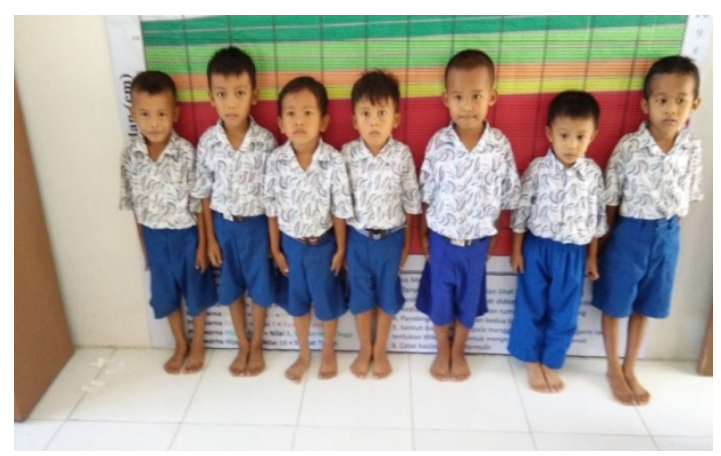

Fig. 3: Collective measurement

chart, length board and $\mathrm{WHO}$ height standard. The training sessions consisted of five topics: (1) Height-for-age standard, WHO-2005, (2) Wall growth chart and gold standard, (3) Interpretation of measurements, (4) Interview using questionnaires and (5) Validity test.

Wall growth chart calibration: Prior to using the wall growth chart to measure the child's height, the tool was first calibrated by using a $200 \mathrm{~cm}$ metal tape. The chart was attached straight and firmly on the wall. Then, a measurement was taken from bottom up to the top, starting from $0 \mathrm{~cm}$ at the bottom and $150 \mathrm{~cm}$ at the top.

Taking measurement: Two enumerators were responsible for each measurement. One focused on the child's age and positioned the child, while the other took the measurement and recorded the result. Each subject was measured twice using the wall growth chart and the gold standard. The measurements were taken individually and collectively (Fig. 2 and 3). 
Data collection and processing: The child's height $(\mathrm{cm})$ was measured using both the wall growth chart and the gold standard. Mean, median, minimum and maximum heights were calculated using SPSS version 17.0. Data were presented in a frequency distribution table.

Sensitivity, specificity and 4 other indices were calculated per validation method. The prevalence of stunting based on the two measurements was also tested. The results were recorded and entered into a $2 \times 2$ table.

\section{RESULTS}

The difference of measurement between the gold standard and the wall growth chart ranged from $0.0 \pm 1.0 \mathrm{~cm}$. As seen in Table 1, 180 measurements taken by the two measurement tools, 58 (32.2\%) measurements presented similar results and the remaining measurements (67.8\%) were not similar, ranging from \pm 0.1 to $\pm 1.0 \mathrm{~cm}$.

Table 2 shows the validity indices based on height status. It indicated that from 190 children, 35 and 32 stunted children detected by the gold standard and wall growth chart, respectively. The validity test showed that the wall growth chart had high sensitivity at $91.0 \%$ and specificity of $92.0 \%$, while the overall predictive value was $90.0 \%$.

Table 3 reveals that the prevalence of stunted children detected by the wall growth chart was higher compared to the gold standard (21.7 vs 19.4\%). However, it was not significantly different $(p<0.05)$.

\section{DISCUSSION}

The aim of the present study was to determine the sensitivity and specificity of the wall growth chart. This modified growth chart is expected to be used as a simple nutrition screening tool in schools. The idea of creating this wall growth chart was not only due to concerns of validity of other tests but also to fulfil the suggestions of the World Health Organization (WHO). The WHO recommended a simple, informative and understandable child growth chart that can be easily interpreted ${ }^{20,21}$. Furthermore, an increasing number of developing countries are currently concerned of child height measurement ${ }^{2-6}$.

The present study revealed that the wall growth chart has high sensitivity (91.5\%) and specificity (92.0\%). This means that the wall growth chart has the ability to correctly identify children who are stunted and normal. Furthermore, the overall predictive value was $81.5 \%$, which shows that in future use, this tool has an ability of atleast $81.5 \%$ in correctly detecting stunted and normal children. The values of mean, minimum, maximum and stunting prevalence are presented in Table 2 and 3, which confirmed that the wall growth chart has high validity. Therefore, the wall growth chart meets the criteria of Habicht ${ }^{10}$ and Gibson ${ }^{22}$, who sought to access more stunted children and to create a cost-effective community nutrition intervention. The screening tool used demonstrated high sensitivity and high positive predictive value.

Table 1: Difference of measurement between gold standard and wall growth chart

\begin{tabular}{lrr}
\hline Delta (cm) & $\mathrm{n}$ & $\%$ \\
\hline-0.6 to -1.0 & 11 & 6.1 \\
-0.1 to -0.5 & 70 & 38.9 \\
$0.0-0.0$ & 58 & 32.2 \\
$0.1-0.5$ & 35 & 19.4 \\
$0.6-1.0$ & 6 & 3.3 \\
\hline Total & 180 & 100.0 \\
\hline
\end{tabular}

Table 2: Validity indices based on height status

\begin{tabular}{|c|c|c|c|c|c|c|c|c|}
\hline \multirow[b]{2}{*}{ Wall growth chart } & \multicolumn{2}{|c|}{ Gold standard } & \multirow[b]{2}{*}{$\mathrm{Se}$} & \multirow[b]{2}{*}{$\mathrm{Sp}$} & \multirow[b]{2}{*}{ PPV } & \multirow[b]{2}{*}{ NPV } & \multirow[b]{2}{*}{$\mathrm{FP}$} & \multirow[b]{2}{*}{$\mathrm{FN}$} \\
\hline & Stunting & Normal & & & & & & \\
\hline Stunting & 32 & 7 & 0.91 & 0.92 & 0.82 & 0.98 & 0.09 & 0.18 \\
\hline Normal & 3 & 138 & & & & & & \\
\hline
\end{tabular}

Se: Sensitivity, Sp: Specificity, PPV: Positive predictive value, NPV: Negative predictive value, FP: False positive, FN: False negative

Table 3: Prevalence of stunting based on measurement tools

\begin{tabular}{|c|c|c|c|c|c|}
\hline \multirow[b]{3}{*}{ Nutrition status } & \multicolumn{4}{|c|}{ Types of tool } & \multirow[b]{3}{*}{$p$-value } \\
\hline & \multicolumn{2}{|c|}{ Growth chart } & \multicolumn{2}{|c|}{ Gold standard } & \\
\hline & $\mathrm{n}$ & $\%$ & $\mathrm{n}$ & $\%$ & \\
\hline Stunting & 39 & 21.7 & 35 & 19.4 & 0.00 \\
\hline Normal & 141 & 78.3 & 145 & 80.6 & \\
\hline
\end{tabular}


Although there are various nutrition screening tools that have been developed due to concerns over the accuracy of the tools, the targets were mostly elderly and adult patients in hospitals ${ }^{11-14}$.

Compared to Sudja's ${ }^{15}$ anthropometric growth chart, in which the sensitivity was $66.0 \%$ and predictive value was $82.0 \%$, present study chart is more reliable for use as a screening tool for children in school. This is because Sudja's growth chart was designed for children aged 6-12 years old, while ours focused on children aged 48-60 months.

For the Indonesia Education Act, the use of this simple growth chart in schools is highly expected because in 2014, the number of kindergarten schools reached 75,000 . There were 5 million students, of whom $80.0 \%$ (3.5 million) were aged 4-5 years old, which renders child growth monitoring as a compulsory program ${ }^{23}$. The Ministry of Health should highly consider the use of this new and simple tool, since the prevalence of stunting was stagnant at 36.7 and $37.2 \%$ since 2013-2015 7 .

The study has certain limitations. It had a small sample size and was a comparison study. This was because of the various nutrition screening tools that had been published, were mostly concerned with adult and elderly patients in hospitals.

\section{CONCLUSION AND FUTURE RECOMMENDATIONS}

It is concluded that it is observed that the wall growth chart has high validity and is simpler compared to another height measurement that was used in schools. Therefore, this new growth chart is highly recommended to be used at school facilities and community health posts.

\section{SIGNIFICANCE STATEMENT}

The current WHO growth chart had been widely used, however, its function was only to monitor growth. It cannot be used to detect stunting in children and needs to expand its function with creation of a communicative and simple screening anthropometric tool. This study will help community health workers and kindergarten teachers to monitor child growth.

\section{REFERENCES}

1. Banerjee, S., R.J.H. Morgan, S.A. Rees and A.H.A. Latif, 2003. Height screening at school: Ineffective without high standards and adequate resources. Arch. Dis. Childhood, 88: 477-481.
2. Agwu, J.C., A. Leishenring and I. Darnley, 2004. Community growth monitoring in practice. Arch. Dis. Childhood, 89: 394-394.

3. National Screening Committee, 2004. Child health sub-group report: Growth disorders. National Screening Committee, Leeds, UK., September 2004.

4. Voss, L.D., J. Mulligan, P.R. Betts and T.J. Wilkin, 1992. Poor growth in school entrants as an index of organic disease: The Wessex growth study. Br. Med. J., 305: 1400-1402.

5. Aszkenasy, M., 2005. Audit of school entry growth screening. Tees and North East Yorkshire NHS Trust, West Lane Hospital, Middlesbrough, UK.

6. Abunain, D., 1988. Tinggi badan dan pertumbuhan anak baru masuk sckolah dasar. Laporan Penelitian, Kantor Meneg, KLH dan Puslitbang Gizi Depkes Rl, Jakarta, Indonesia.

7. Ministry of Health, 2015. Hasil survey pemantauan status gizi. Kemenkes RI survey PSG, Ministry of Health, Indonesia.

8. Ministry of Health, 2016. Hasil survey pemantauan status gizi. Kemenkes RI survey PSG, Ministry of Health, Indonesia.

9. Morton, R.F., J.R. Hebel and R.J. McCarter, 2003. Panduan Studi Epidemiologi dan Biostatistika. 5th Edn., Penerbit Buku Kedokteran, Indonesia.

10. Habicht, J.P., 1980. Some characteristics of indicators of nutritional status for use in screening and surveillance. Am. J. Clin. Nutr., 33: 531-535.

11. Spagnuolo, M.l., I. Liguoro, F. Chiatto, D. Mambretti and A. Guarino, 2013. Application of a score system to evaluate the risk of malnutrition in a multiple hospital setting. Ital. J. Pediatr., Vol. 39. 10.1186/1824-7288-39-81.

12. Charlton, K.E., T.L. Kolbe-Alexander and J.H. Nel, 2005. Development of a novel nutrition screening tool for use in elderly South Africans. Public Health Nutr., 8: 468-479.

13. Leistra, E., J.A.E. Langius, A.M. Evers, M.A.E. van Bokhorst-de van der Schueren, Visser, M., H.C.W. de Vet and H.M. Kruizenga, 2013. Validity of nutritional screening with MUST and SNAQ in hospital outpatients. Eur. J. Clin. Nutr., 67: 738-742.

14. Huysentruyt, K., T. Devreker, J. Dejonckheere, J. de Schepper, Y. Vandenplas and F. Cools, 2015. Accuracy of nutritional screening tools in assessing the risk of undernutrition in hospitalized children. J. Pediatr. Gastroenterol. Nutr., 61: 159-166.

15. Sudja, A., 2017. Sensitivitas dan spesifisitas anthropometric wall chart untuk mendeteksi stunted pada anak sekolah dasar. Poltekkes Kemenkes Bandung, Bandung, Indonesia.

16. Susanto, A., 2016. Teori dan praktek. Pendidikan Anak Usia Dini, Penerbit Bumi Aksara, Indonesia.

17. Badan Pusat Statistik Kabupaten Deli Serdang, 2015. Kabupaten Deli Serdang dalam angka. Badan Pusat Statistik Kabupaten Deli Serdang, Indonesia.

18. WHO., 2005. The WHO multicentre growth reference study (MGRS). World Health Organization, Rome, Italy. 
19. Kementerian Kesehatan RI., 2011. Standar anthropometri penilaian status gizi anak. Kepmenkes RI Nomor 1995/Menkes/SK/XII/2010, Kementerian Kesehatan RI., Direktorat Jenderal Bina Gizi dan Kesehatan Ibu dan Anak, Direktorat Bina Gizi, Indonesia.

20. Sinaga, H.T., Mahdiah and M. Manalu, 2015. Using modified growth chart in Posyandu effectively improved child weight gain in Deli Serdang district, Indonesia. Pak. J. Nutr., 14: 547-552.
21. Ben-Joseph, E.P., S.A. Dowshen and N. Izenberg, 2009. Do parents understand growth charts? A national, internet-based survey. Pediatrics, 124: 1100-1109.

22. Gibson, R.S., 2005. Principle of Nutritional Assessment. 2nd Edn., Oxford University Press, New York, USA., Pages: 908.

23. Kementerian Pendidikan dan Kebudayaan, 2014. Statistik pendidikan anak usia dini. Sektretarian Jenderal Pusat Data dan Pendidikan, Indonesia. 